\title{
Improving Fertility of Maghrabian She-Camels Treated with Different Hormonal Treatments during Breeding Season in Egypt
}

\author{
T.H. Mostafa*, A.M. Abd El-Salaam*, A.S.S. Abdoon**, \\ A.E. Abdel-Khalek*** \\ *Animal Production Research Institute, Ministry of Agriculture, Egypt. \\ **Department of Animal Reproduction and AI, National Research Center, Egypt. \\ ***Animal Production Department, Faculty of Agriculture, Mansoura University, Egypt.
}

\begin{abstract}
To achieve estrous synchronization in 28 mature dromedary she-camels, four groups (7 in each), included animals i.m. injected with $250 \mu \mathrm{g}$ GnRH analogue on day 0 and $5 \mathrm{ml} P G F_{2} \alpha$ on day 10 (G1); CIDR for 10 days and $1000 \mathrm{IU}$ eCG on day 8 (G2); $1000 \mathrm{IU}$ eCG on day 0 and $5 \mathrm{ml} \mathrm{PGF} \mathrm{F}_{2} \alpha$ on day 10 (G3); control (G4). At the end of treatment, animals in heat were naturally mated. Results showed that follicular diameter (FD) decreased in G2 pre-treatment, increased in G2 and G3 and decreased in G1 at mating compared with G4 $(P<0.05)$. FD was wider $(P<0.05)$ in pregnant $(P)$ than in non-pregnant $(N P)$ animals. Estrus rate was $100 \%$ in all groups; estrus incidence and mating time were the longest in G4 (170.6 and $198.6 \mathrm{~h})$ and the shortest in G2 $(72.0$ and $75.7 h)$, being shorter in $P$ than in NP. $(P<0.05)$. In all groups, $P 4$ was similar pre-treatment, lower at mating and higher on day 70 post-mating in $P$ than in NP $(P<0.05)$. E2 was higher $(P<0.05)$ in NP than in $P$ on day 70 post-mating. Pregnancy rate was $57.14,85.71,71.43$ and $42.86 \%$ in G1, G2, G3 and G4, respectively $(P<0.05)$. Total number of CLs decreased in all treated groups, while CL diameter decreased in Gl as compared to G4 $(P<0.05)$. Estrus/ovulation and higher pregnancy rate of camel could be hormonally induced by CIDR insertion for 10 days and eCG injection on day 8 of CIDR insertion.
\end{abstract}

Keywords: Camel, estrous synchronization, GnRH, CIDR, eCG, progesterone, estrogen, pregnancy rate.

\section{Introduction}

Dromedary camels (one-humped) have been an important role as a source of meat and milk in Egypt. Low reproductive efficiency of the camel had been reported (Kaufmann, 2005), due to the short breeding season, long lactation period and generally only one calf is produced every two years for each female (Minoia $\boldsymbol{e} t$ al., 1992).

Camels are seasonally polyestrous animals with estrous cycle differed from that in other farm animals. The estrous cycle in camel is characterized by three phases lasting 24-28 days (Shalash, 1987) with absence of the luteal phase (Al-Sobayil, 2003). These phases include follicular growth, existence of mature follicles (estrous period) and follicular atresia. The estrous period is longer up to up to 8 days (Tibary and Anouassi, 1996). Ovulation in camel actually occurs mechanically by natural mating or induces by hormonal treatments (Al-Sobayil, 2003). The estrous signs in a female camel are characterized by the sitting of the camel to be mounted by other females, restlessness, frequent salivation, swelling of the vulva, vaginal mucous discharge, frequent urination (especially when the male comes close to her), and finally the acceptance of mating by the male (Homeida et al., 1988).

Estrous synchronization for improving the reproductive performance is used in reproductive programs of most farm animals. Great attention of several researchers has been focused on different regimens of estrous synchronization in farm animals (Dahir $\boldsymbol{e t}$ al., 1990; Elias $\boldsymbol{e t}$ al., 1985). The progress in the methods of hormone extraction, purification and measurements of their concentrations in blood circulation has risen understanding the mechanisms of regulating reproduction in farm animals (Combarnous and Anouassi, 1994).

Understanding the hormonal changes throughout the estrous cycle of the she-camel extremely helped in the application of different hormonal combinations to induce and synchronize the estrus. As in other mammals, estrous synchronization in camels using hormonal treatments stimulates growth and development of the ovarian follicles and ovulation. In previous reports, estrous synchronization in the she-camel was based on the use of several hormones, including PMSG (Elias et al. 1985; Anouassi and Ali, 1991), hCG or LH (Shalash, 1987; Anouassi and Ali, 1991), GnRH with LH or hCG (Chen et al. 1985; Bono et al. 1991 a\&b), or GnRH, LH or its analogue, and hCG (Skidmore et al., 1996; Hafez and Hafez, 2001).

Induction of ovulation by GnRH or LH depends mainly on the dominant follicle size at the time of hormone injection. When she-camels with the existence of an ovarian dominant follicle ( $<10 \mathrm{~mm}$ in diameter) were given LH, ovulation response approached 90\% (Anouassi et al., 1994; Skidmore $\boldsymbol{e t}$ al., 1996) after 26-28 h of i.m. or i.v. GnRH (0.5-1 mg) injection (Musa et al., 1993). However, eCG was used to stimulate follicular 
growth in order to induce the estrus during out of breeding season at a range from 1500-7000 IU (Agarwal $\boldsymbol{e t}$ al., 1993; Al-Sobayil, 2003).

Estrus also could be synchronized in she-camel using hormonal combination including progesterone (P4) or its analogue either as daily injection or as an intra-vaginal releasing the device of PRID for a period of 10-20 days, followed by eCG injection (1500-2000 IU) $24 \mathrm{~h}$ before or on day of the device withdrawal (Tibary and Anouassi, 1997). However, estrous synchronization with timed artificial insemination (AI) in dromedary she-camels was carried out using hCG, Progesterone Release Intra-vaginal Device (PRID) for 17 days plus hCG or PRID plus eCG (Al-Sobayil, 2008). In addition, Controlled Intra-vaginal Drug Releasers (CIDR) proved to control ovarian activity in llama (Chaves et al., 2002).

She-camel mostly does not ovulate without a natural mating or hormonal induction, and to reproductively manage a herd of she-camels, this requires laborious efforts of the owner and might result in incorrigible outcomes. Therefore, there existed a need for the estrus/ovulation synchronization of She-camels (Al-Sobayil, 2008). Most of the previous attempts are still missing a complete regimen for induction and synchronization of estrus in the she-camel, and of contraversing results.

To offer a new insight into estrous synchronization in she-camel during breeding season, the current study aimed to compare three hormonal protocols $\left(\mathrm{GnRH}+\mathrm{PGF}_{2} \alpha, \mathrm{CIDR}+\mathrm{eCG}\right.$ and $\left.\mathrm{eCG}+\mathrm{PGF}_{2} \alpha\right)$ for estrous synchronization in dromedary she-camel and consequently their effects on pregnancy rate by applying the natural insemination at the synchronized estrus.

\section{Materials and Methods}

This study was carried out at Center of Studies and Development of Camel Production, belonging to Animal Production Research Institute, Agricultural Research Center, Marsa Matrouh Governorate, Egypt, during the breeding season.

Animals:

Twenty eight sexually mature dromedary she-camels having 460-550 kg live body weight, 8-13 years old and 2-5 parities were used in this study. Animals were randomly divided into four similar groups, 7 animals in each. All animals were fed a daily basal diet consisting of $3.5 \mathrm{~kg}$ concentrate feed mixture (CFM), $2.5 \mathrm{~kg}$ clover hay $(\mathrm{CH})$ and $2 \mathrm{~kg}$ rice straw (RS) per animal. Chemical analysis of CFM, BH and RS are shown in Table 1. Ingredient of the CFM used in feeding all the experimental animals was composed of $25 \%$ wheat bran, $25 \%$ yellow corn, $9 \%$ un-corticated cotton seed meal, $20 \%$ barely, $15 \%$ rice brain, $3 \%$ molasses, $2 \%$ premix and $1 \%$ common salt.

Table 1. Chemical analysis of different feedstuffs in the basal diet of she-camels in all groups.

\begin{tabular}{|c|c|c|c|}
\hline Item & Concentrate mixture & Clover hay & Rice straw \\
\hline Dry matter $(\%)$ & 89.44 & 89.00 & 88.46 \\
\hline \multicolumn{4}{|c|}{ Chemical analysis (on dry matter basis, \%): } \\
\hline Organic matter & 92.43 & 87.70 & 82.24 \\
\hline Crude fiber & 08.85 & 30.50 & 35.69 \\
\hline Crude protein & 12.24 & 11.30 & 02.53 \\
\hline Ether extract & 04.64 & 03.20 & 01.52 \\
\hline Nitrogen free extract & 66.70 & 37.70 & 40.50 \\
\hline Ash & 07.57 & 12.30 & 19.76 \\
\hline
\end{tabular}

\section{Experimental Groups:}

In this study, four similar experimental groups were used as the following:

G1: Each animal was i.m. injected with $250 \mu \mathrm{g}$ GnRH analogue (buserelin acetate; Receptal, Intervet International, Germany) on day 0 , followed by $5 \mathrm{ml} \mathrm{PGF}_{2} \alpha$ (Intervet, B.V., Boxmer, Holland) on day 10, and animals in heat within $72 \mathrm{~h}$ of $\mathrm{PGF}_{2} \alpha$ injection were naturally inseminated.

G2: Controlled Internal Drug Release (CIDR) containing $1.9 \mathrm{~g}$ of progesterone (EAZI-BREED CIDRTM, Interag, Hamilton, New Zealand) was intravaginally inserted in each animal on day 0, followed by injection of 1000 IU eCG (Synncropart, Ceva Sante Animal, France) on day 8. CIDR was removed on day 10 and then animals in heat were naturally inseminated within 72-120 h of CIDR withdrawal. The CIDR was inserted by restraining the female camel in a regular chute and the vulva was cleaned, disinfected and lubricated. The device was loaded into the applicator and gently was inserted into the vagina leaving a free portion of the string outside the vulva to facilitate its withdrawal.

G3: Each animal was i.m. injected with $1000 \mathrm{IU}$ eCG on day 0 , followed by $5 \mathrm{ml} \mathrm{PGF}_{2} \alpha$ injection on day 10 and natural insemination of animals in heat within $72 \mathrm{~h}$ of $\mathrm{PGF}_{2} \alpha$ injection.

G4: Animals were left without hormonal treatment and saved as control. 
All she-camels observed in heat following each protocol or in control group were naturally inseminated with fertile camel bull

\section{Ultrasonograhy Examination:}

She-camels were examined by ultrasound scanner Vetson-color machine (Kontron Medical, France) with endo-rectal ultrasound multi-frequency probe 5 LV (2-7 MHZ). Animals were scanned through the rectal mucosa to identify diameter of follicles at different sizses pre-treatment and at mating as well as number and diameter of corpora lutea (CLs) on day 70 post-mating on the right and left ovaries of each animal. Follicles and CLs were measured through a built-in caliper system inside the machine.

\section{Blood Sampling:}

Blood samples were collected from all animals in each group on days 0 (pre-treatment), at mating and on day 70 post-mating. Bleeding was done before morning feeding from the jugular vein-puncture into clean test-tubes. The test-tubes and their contents were allowed to stand for about six hours, and blood serum was separated carefully into vials. Serum samples were stored in deep freezer $\left(-20^{\circ} \mathrm{C}\right)$ before being analyzed for progesterone $(\mathrm{P} 4)$ and estradiol-17 $\beta$ (E2). Both $\mathrm{P} 4$ and E2 assays were determined using chemical commercial kits and performed by RIA.

\section{Estrus and Conception:}

Animals in heat relative to total animals in each group were recorded to determine estrus rate. Also, time elapsed from the PGF2 injection (G1 and G3), CIDR withdrawal (G2) or start of treatment (G4) to estrus and mating was calculated. All inseminated animals were diagnosed for pregnancy on day 20-40 of mating using ultrasonographic examination to determined pregnancy rate based on total number of animals or number of inseminated animals in each group.

\section{Statistical Analysis}

Data were collected and statically analyzed by using the General Linear Model (GLM) procedures of the statistical Analysis Systems (SAS, 2004). Data obtained were tested by analysis of variance with one way design to test the group differences according to the following model: $Y i j=\mu+P_{i}+e_{i j}$; where: Yij= observed values, $\mu=$ overall mean, $\mathrm{P}_{\mathrm{i}}=$ experimental group and $\mathrm{e}_{\mathrm{ij}}=$ Random error. Values were given as mean \pm standard error. All statements of significance were based on $\mathrm{P}<0.05$ using Duncan's Multiple Range (Duncan, 1955).

\section{Ovarian Follicles:}

\section{Results And Discussion}

Pre-treatment (Day 0), follicular diameter was higher $(\mathrm{P}<0.05)$ in G4 and G3 than in $\mathrm{G} 2$, which showed the lowest diameter, but these groups did not differ from that in G1 (Table 2). This means that camel in CIDR group showed the lowest diameter for all follicles and the largest follicles on both ovarian sides as compared other groups before treatment.

At the end of treatment (at mating), follicular diameter (for all follicles or largest follicles) was the highest $(\mathrm{P}<0.05)$ in $\mathrm{G} 2$ and G3, moderate in G4 and the lowest in G1 (Table 3). Such trend of change in follicular diameter at mating in comparing with at 0 day may indicate pronounced effect of CIDR or eCG treatment on follicular growth and development more than of OvSynch protocol.

Pre-treatment ( 0 day), there were insignificant differences in the follicular diameter between pregnant and non-pregnant camels in each group or overall for all groups. However, at mating, diameter of largest or all visible follicles on both ovarian sides was wider $(\mathrm{P}<0.05)$ wider in pregnant than in non-pregnant camels in all groups. This trend was nearly observed within each group (Table 3 ).

It is of interest to note that follicular growth was evident on the ovaries of untreated camels (G1) on 0 day or at mating in most camels with clearly mature follicles. Similar findings were observed in control camels during breeding season in September and October (Dholpuria et al., 2012). The season affects the growth of dominant follicle during its dominance period but the other characteristics of the follicular wave are not affected (Manjunatha et al., 2012). No ovarian cysts were observed in CIDR or eCG group. In both groups, camels were injected with eCG at a level of 1000 IU. Quzy et al. (2013) detected ovarian cysts developed with doses of $2000 \mathrm{IU}$ of eCG which could be due to prolonged half life of $72 \mathrm{~h}$ seen with eCG. However, lower doses as 1000 IU given by Agarwal et al. (1997) for 2 consecutive days after $\mathrm{P}_{4}$ injection resulted in ovulation in 50$75 \%$ camels only without ovarian cyst. The observed highest diameter of the largest follicles in CIDR group may suggest that $\mathrm{P}_{4}$ priming before eCG would be beneficial although this delays the appearance of ovulatory size mature follicle (Monaco et al., 2012). 
Table 2. Follicular diameter pre-treatment and at mating on the left and right side as affected by hormonal protocol.

\begin{tabular}{|c|c|c|c|c|c|}
\hline \multirow{3}{*}{$\begin{array}{c}\text { Group } \\
\text { (Protocol) }\end{array}$} & \multicolumn{5}{|c|}{ Follicular diameter (mm) } \\
\hline & \multicolumn{2}{|c|}{ Left ovary } & \multicolumn{2}{|c|}{ Right ovary } & \multirow{2}{*}{$\begin{array}{c}\text { Overall } \\
\text { mean/animal }\end{array}$} \\
\hline & Largest follicle & All follicles & Largest follicle & All follicles & \\
\hline \multicolumn{6}{|c|}{ Day 0 (pre-treatment): } \\
\hline G1 (OvSynch) & $8.00 \pm 0.833$ & $7.00 \pm 0.636$ & $4.86 \pm 0.375$ & $4.36 \pm 0.445$ & $5.68 \pm 0.509^{\mathrm{ab}}$ \\
\hline G2 (CIDR) & $7.86 \pm 1.952$ & $5.43 \pm 1.170$ & $4.14 \pm 1.069$ & $4.07 \pm 1.018$ & $4.75 \pm 0.219^{b}$ \\
\hline G3 (eCG) & $8.00 \pm 0.537$ & $7.57 \pm 0.487$ & $5.29 \pm 0.749$ & $4.93 \pm 0.406$ & $6.25 \pm 0.380^{\mathrm{a}}$ \\
\hline G4 (Control) & $8.14 \pm 0.560$ & $7.86 \pm 0.476$ & $6.86 \pm 0.560$ & $6.50 \pm 0.433$ & $7.18 \pm 0.445^{\mathrm{a}}$ \\
\hline \multicolumn{6}{|l|}{ At mating: } \\
\hline G1 (OvSynch) & $8.00 \pm 1.272$ & $5.57 \pm 0.783^{\mathrm{b}}$ & $5.29 \pm 0.315^{\mathrm{b}}$ & $4.71 \pm 0.312^{\mathrm{b}}$ & $4.54 \pm 0.417^{\mathrm{c}}$ \\
\hline G2 (CIDR) & $10.90 \pm 1.030$ & $7.93 \pm 0.424^{\mathrm{ab}}$ & $9.71 \pm 0.857^{\mathrm{a}}$ & $7.93 \pm 0.424^{\mathrm{a}}$ & $7.20 \pm 0.164^{\mathrm{a}}$ \\
\hline G3 (eCG) & $10.29 \pm 0.668$ & $8.50 \pm 0.360^{\mathrm{a}}$ & $8.57 \pm 0.715^{\mathrm{a}}$ & $7.57 \pm 0.487^{\mathrm{a}}$ & $7.84 \pm 0.354^{\mathrm{a}}$ \\
\hline G4 (Control) & $10.00 \pm 1.077$ & $8.50 \pm 0.360^{\mathrm{a}}$ & $5.86 \pm 0.698^{\mathrm{b}}$ & $5.21 \pm 0.562^{\mathrm{b}}$ & $6.82 \pm 0.421^{b}$ \\
\hline
\end{tabular}

Means denoted within the same column at each sampling time with different superscripts are significantly different at $\mathrm{P}<0.05$.

Table 3. Follicular diameter pre-treatment and at mating on the left and right side of pregnant and nonpregnant camels within each hormonal protocol.

\begin{tabular}{|c|c|c|c|c|c|c|}
\hline \multirow{3}{*}{$\begin{array}{c}\text { Group } \\
\text { (Protocol) }\end{array}$} & \multirow{3}{*}{$\begin{array}{c}\text { Pregnancy } \\
\text { status }\end{array}$} & \multicolumn{5}{|c|}{ Follicular diameter $(\mathbf{m m})$} \\
\hline & & \multicolumn{2}{|c|}{ Left ovary } & \multicolumn{2}{|c|}{ Right ovary } & \multirow[b]{2}{*}{$\begin{array}{c}\text { Overall mean } \\
\text { per animal }\end{array}$} \\
\hline & & $\begin{array}{l}\text { Largest } \\
\text { follicle }\end{array}$ & All follicles & $\begin{array}{l}\text { Largest } \\
\text { follicle }\end{array}$ & $\begin{array}{c}\text { All } \\
\text { follicles }\end{array}$ & \\
\hline \multicolumn{7}{|c|}{ Day 0 (pre-treatment): } \\
\hline \multirow{2}{*}{ G1 (OvSynch) } & Non-preg. & $7.33 \pm 0.733$ & $6.33 \pm 0.604$ & $4.66 \pm 0.273$ & $4.17 \pm 0.227$ & $5.50 \pm 0.432$ \\
\hline & Pregnant & $8.50 \pm 0.859$ & $7.12 \pm 0.681$ & $5.00 \pm 0.416$ & $4.50 \pm 0.510$ & $5.81 \pm 0.557$ \\
\hline \multirow{2}{*}{ G2 (CIDR) } & Non-preg. & $8.00 \pm 0.000$ & $5.00 \pm 0.000$ & $4.00 \pm 0.000$ & $4.00 \pm 0.000$ & $4.50 \pm 0.000$ \\
\hline & Pregnant & $7.83 \pm 0.890$ & $5.50 \pm 0.527$ & $4.16 \pm 0.487$ & $4.08 \pm 0.164$ & $4.79 \pm 0.232$ \\
\hline \multirow{2}{*}{ G3 (eCG) } & Non-preg. & $7.07 \pm 1.834$ & $5.25 \pm 1.343$ & $3.67 \pm 0.991$ & $3.81 \pm 0.981$ & $4.50 \pm 1.081$ \\
\hline & Pregnant & $8.20 \pm 0.553$ & $7.90 \pm 0.464$ & $6.00 \pm 0.589$ & $5.10 \pm 0.425$ & $6.50 \pm 0.367$ \\
\hline \multirow{2}{*}{$\begin{array}{c}\text { G4 } \\
(\text { Control }) \\
\end{array}$} & Non-preg. & $7.52 \pm 1.430$ & $7.22 \pm 1.350$ & $5.78 \pm 1.173$ & $5.14 \pm 1.030$ & $6.17 \pm 1.157$ \\
\hline & Pregnant & $8.00 \pm 0.961$ & $7.83 \pm 0.843$ & $7.00 \pm 0.961$ & $6.67 \pm 0.843$ & $7.25 \pm 0.841$ \\
\hline \multirow{2}{*}{$\begin{array}{c}\text { Overall } \\
\text { mean }\end{array}$} & Non-preg. & $7.80 \pm 0.316$ & $7.05 \pm 0.356$ & $5.20 \pm 0.474$ & $5.10 \pm 0.351$ & $6.08 \pm 0.332$ \\
\hline & Pregnant & $8.11 \pm 0.437$ & $6.92 \pm 0.409$ & $5.33 \pm 0.398$ & $4.89 \pm 0.353$ & $5.91 \pm 0.332$ \\
\hline \multicolumn{7}{|l|}{ At mating: } \\
\hline \multirow{2}{*}{ G1 (OvSynch) } & Pregnant & $9.00 \pm 0.480$ & $6.16 \pm 0.500$ & $5.00 \pm 0.000$ & $4.50 \pm 0.000$ & $4.63 \pm 0.301$ \\
\hline & Non-preg. & $7.25 \pm 1.454$ & $5.13 \pm 0.863$ & $5.50 \pm 0.368$ & $4.87 \pm 0.401$ & $4.47 \pm 0.475$ \\
\hline \multirow{2}{*}{ G2 (CIDR) } & Pregnant & $7.00 \pm 0.000$ & $7.00 \pm 0.000$ & $7.00 \pm 0.000$ & $6.00 \pm 0.000$ & $6.50 \pm 0.000$ \\
\hline & Non-preg. & $11.50 \pm 0.941$ & $8.08 \pm 0.425$ & $10.17 \pm 0.764$ & $6.33 \pm 0.569$ & $7.31 \pm 0.113$ \\
\hline \multirow{2}{*}{ G3 (eCG) } & Pregnant & $9.84 \pm 2.595$ & $7.20 \pm 1.709$ & $8.69 \pm 2.284$ & $7.15 \pm 1.740$ & $6.51 \pm 1.538$ \\
\hline & Non-preg. & $9.60 \pm 0.565$ & $8.90 \pm 0.204$ & $9.00 \pm 0.589$ & $8.23 \pm 0.224$ & $7.10 \pm 0.425$ \\
\hline \multirow{2}{*}{$\begin{array}{c}\text { G4 } \\
\text { (Control) }\end{array}$} & Pregnant & $9.02 \pm 1.697$ & $7.96 \pm 1.487$ & $7.14 \pm 1.709$ & $6.26 \pm 1.459$ & $6.84 \pm 1.390$ \\
\hline & Non-preg. & $10.00 \pm 0.480$ & $8.33 \pm 0.139$ & $5.67 \pm 0.555$ & $5.17 \pm 0.555$ & $7.33 \pm 0.284$ \\
\hline \multirow{2}{*}{$\begin{array}{c}\text { Overall } \\
\text { mean }\end{array}$} & Pregnant & $9.20 \pm 0.451$ & $7.45 \pm 0.391$ & $6.10 \pm 0.529^{b}$ & $5.40 \pm 0.407^{b}$ & $5.99 \pm 0.373^{b}$ \\
\hline & Non-preg. & $10.11 \pm 0.684$ & $8.03 \pm 0.505$ & $8.07 \pm 0.595^{\mathrm{a}}$ & $6.89 \pm 0.425^{\mathrm{a}}$ & $6.94 \pm 0.371^{\mathrm{a}}$ \\
\hline
\end{tabular}

Means denoted within the same column with different superscripts are significantly different at $\mathrm{P}<0.05$.

It is worth noting that mature follicles were seen on day 0 (the largest diameter of about $8 \mathrm{~mm}$ ) and at mating (the largest diameter of 8-10.9 mm), particularly on the left ovaries in all groups. In camel administrated with $2000 \mathrm{IU}$ of eCG or an OvSynch protocol (GnRH+PGF2 $\alpha+\mathrm{GnRH}$ on 0,7 and 9 days), a high proportion of eCG treated and OvSynch treated camels evidenced a mature follicle on day 8 and 12 of treatment, respectively (Quzy et al., 2013). In this respect, Skidmore et al. (2009) observed mature follicles on the ovaries of camels treated with GnRH (Day 0), followed by PGF2 $\alpha$ on day 7. Also, Al-Sobayil (2008) reported that mature follicles were visible on the camel ovaries on day 12 of the OvSynch protocol. Similar findings were also recorded previously by Bono et al. (1991a). 
Generally, eCG was used as a hormonal treatment for inducing ovarian follicle growth in camels during the non-breeding season (Al-Sobayil, 2003 and 2008) with high success rates and evidence of ovulatory sized follicles on day 13 when eCG was used in succession to vaginal implants of progesterone releasing intra-vaginal device used for cattle; CIDR-B (Al-Sobayil, 2008; Monaco et al., 2012).

\section{Estrus Rate:}

All treated and control camels exhibited estrous activity at different times after the end of treatment for each group. Time of estrus incidence and subsequently of mating after the end of each treatment was longer $(\mathrm{P}<0.05)$ in $\mathrm{G} 4$ (control) than in treated groups, being the shortest in $\mathrm{G} 2$ as compared to G1 and G3.Overall mean of Time of estrus/mating was shorted $(\mathrm{P}<0.05)$ shorter in pregnant than in non-pregnant of all groups and this trend was recorded within each group (Tables 4 and 5).

Table 4. Estrus rate and time of estrus incidence and mating after the end of hormonal treatment.

\begin{tabular}{|l|c|c|c|c|c|}
\hline \multirow{2}{*}{$\begin{array}{c}\text { Group } \\
\text { (Protocol) }\end{array}$} & \multirow{2}{*}{$\begin{array}{c}\text { Estrus } \\
\text { rate }(\%)\end{array}$} & \multicolumn{2}{c|}{$\begin{array}{c}\text { Estrus incidence after the } \\
\text { end of treatment }(\mathbf{h})\end{array}$} & \multicolumn{2}{c|}{$\begin{array}{c}\text { Mating incidence after the } \\
\text { end of treatment (h) }\end{array}$} \\
\cline { 3 - 6 } & & Range & Mean \pm SE & Range & Mean \pm SE \\
\hline G1 (OvSynch) & 100 & $72-120$ & $106.3 \pm 17.57^{\mathrm{b}}$ & $73-132$ & $111.3 \pm 21.47^{\mathrm{b}}$ \\
\hline G2 (CIDR) & 100 & $24-120$ & $72.0 \pm 13.94^{\mathrm{b}}$ & $27-122$ & $75.7 \pm 24.02^{\mathrm{b}}$ \\
\hline G3 (eCG) & 100 & $48-120$ & $92.6 \pm 15.04^{\mathrm{b}}$ & $56-134$ & $101.1 \pm 26.66^{\mathrm{b}}$ \\
\hline G4 (Control)* & 100 & $144-192$ & $170.6 \pm 20.74^{\mathrm{a}}$ & $176-222$ & $198.6 \pm 18.96^{\mathrm{a}}$ \\
\hline
\end{tabular}

Means denoted within the same column with different superscripts are significantly different at $\mathrm{P}<0.05$.

* At the same time of starting other hormonal treatments.

Table 5. Estrus and mating incidence after the end of hormonal treatment in pregnant and non-pregnant camels within each hormonal protocol.

\begin{tabular}{|l|l|c|c|}
\hline \multicolumn{1}{|c|}{$\begin{array}{c}\text { Group } \\
\text { (Protocol) }\end{array}$} & \multicolumn{1}{|c|}{$\begin{array}{c}\text { Pregnancy } \\
\text { staus }\end{array}$} & $\begin{array}{c}\text { Estrus incidence after the } \\
\text { end of treatment (h) }\end{array}$ & $\begin{array}{c}\text { Mating incidence after the } \\
\text { end of treatment (h) }\end{array}$ \\
\hline \multirow{2}{*}{ G1 (OvSynch) } & Non-pregnant & $120.0 \pm 0.00$ & $130.0 \pm 4.27$ \\
& Pregnant & $96.0 \pm 7.35$ & $97.3 \pm 7.45$ \\
\hline \multirow{2}{*}{ G2 (CIDR) } & Non-pregnant & $82.0 \pm 0.00$ & $94.0 \pm 0.00$ \\
& Pregnant & $76.6 \pm 15.16$ & $78.3 \pm 15.20$ \\
\hline \multirow{2}{*}{ G3 (eCG) } & Non-pregnant & $120.0 \pm 0.00$ & $131.0 \pm 2.50$ \\
& Pregnant & $74.7 \pm 14.59$ & $77.9 \pm 14.76$ \\
\hline \multirow{2}{*}{ G4 (control) } & Non-pregnant & $137.3 \pm 30.10$ & $154.2 \pm 34.30$ \\
& Pregnant & $81.9 \pm 32.22$ & $88.5 \pm 37.55$ \\
\hline \multirow{2}{*}{ Overall mean } & Non-pregnant & $141.0 \pm 12.46^{\mathrm{a}}$ & $157.4 \pm 14.70^{\mathrm{a}}$ \\
& Pregnant & $93.3 \pm 8.86^{\mathrm{b}}$ & $101.8 \pm 10.70^{\mathrm{b}}$ \\
\hline
\end{tabular}

Overall means denoted within the same column with different superscripts are significantly different at $\mathrm{P}<0.05$.

In comparable with the present results, different rates and times of estrus incidence were recorded by Al-Sobayil (2008) for she-camel treated with eCG+hCG (T1); and PRID for 17 days and hCG (G2) or eCG (G3) at the time of device removal. Estrus rate was 20, 40 and 100\% during breeding season, respectively. The estrous exhibition started 24 hours after the device removal and after the hCG injection. In accordance with the present results, the later author indicated that synchronizing female camels with progestagen in addition to the administration of an ovulatory hormone may result in a better estrous exhibition within a narrower period. Also, Ismail et al. (1998) offered a possibility to prolong the limited breeding season of the she-camel by a single injection with hCG followed by a single injection with PGF2 $\alpha$ (Anouassi and Ali, 1991; Minoia et al. 1992).

Generally, eCG is the most widely used treatment for inducing high estrus rate in camels (Al-Sobayil, 2008; Monaco et al., 2012). Also, the use of exogenous $\mathrm{P} 4$ for controlling the ovulation has been documented in dromedary camel (McKinnon et al., 1994), Bactrian camels (Nikjou et al., 2008) and IIama (Chaves et al., 2002). Although the OvSynch protocol is widely used for timed insemination in cattle, it less frequent for camel, but the use of GnRH alone (Ismail et al., 1998) or in combination with P4 implants (Monaco et al., 2012) has been suggested for estrus and ovulation induction in camels.

\section{Hormonal Profile:}

The differences in overall mean of $\mathrm{P}_{4}$ concentration between groups were not significant pre-treatment, at mating and on day 70 post-mating; however, there was a marked increase in $\mathrm{P}_{4}$ concentration at mating 
compared with pre-treatment and on day 70 post-mating in comparing with at mating in all groups (Table 6). In this respect, Derara et al. (2014) found that CL was detected by day $4.1 \pm 1.6$ after GnRH treatment and lasted for 6.0 \pm 1.1 days. Thereafter, serum $\mathrm{P}_{4}$ was at basal values and increased only after $\mathrm{GnRH}$ treatment. Also, Chaves et al. (2002) stated a rapid increase in plasma $\mathrm{P}_{4}$ concentration in IIama immediately after the insertion of intravaginal device, and then $\mathrm{P}_{4}$ concentration sharply decreased until day 3 , and slowly decreased until basal values were registered on day 11-13 post insertion.

Table 6. Mean and standard error of progesterone and estradiol-17- $\beta$ concentrations in blood serum of She-camels as affected by hormonal protocol.

\begin{tabular}{|l|c|c|c|c|c|c|}
\hline \multirow{2}{*}{ Protocol } & \multicolumn{3}{|c|}{ Progesterone level $(\boldsymbol{\mu g} / \mathbf{m l})$} & \multicolumn{3}{c|}{ Estrogen level (pg/ml) } \\
\cline { 2 - 7 } & $\begin{array}{c}\text { Pre- } \\
\text { treatment }\end{array}$ & At mating & $\begin{array}{c}\mathbf{7 0} \text { d of } \\
\text { mating }\end{array}$ & $\begin{array}{c}\text { Pre- } \\
\text { treatment }\end{array}$ & At mating & $\begin{array}{c}\mathbf{7 0 ~ d ~ o f ~} \\
\text { mating }\end{array}$ \\
\hline G1 (OvSynch) & $0.67 \pm 0.083$ & $1.19 \pm 0.025$ & $4.11 \pm 0.813$ & $0.19 \pm 0.064^{\mathrm{c}}$ & $6.05 \pm 1.807^{\mathrm{a}}$ & $0.02 \pm 0.005^{\mathrm{b}}$ \\
\hline G2 (CIDR) & $1.08 \pm 0.195$ & $1.43 \pm 0.257$ & $4.55 \pm 1.683$ & $2.60 \pm 0.558^{\mathrm{b}}$ & $5.59 \pm 0.897^{\mathrm{a}}$ & $2.58 \pm 0.086^{\mathrm{b}}$ \\
\hline G3 (eCG) & $0.30 \pm 0.065$ & $1.06 \pm 0.370$ & $5.06 \pm 1.845$ & $6.23 \pm 0.425^{\mathrm{a}}$ & $2.18 \pm 0.360^{\mathrm{b}}$ & $1.61 \pm 0.519^{\mathrm{b}}$ \\
\hline G4 (Control) & $1.02 \pm 0.790$ & $1.92 \pm 0.447$ & $3.90 \pm 0.525$ & $2.98 \pm 0.959^{\mathrm{b}}$ & $4.49 \pm 1.637^{\mathrm{ab}}$ & $3.13 \pm 1.044^{\mathrm{a}}$ \\
\hline
\end{tabular}

Means denoted within the same column with different superscripts are significantly different at $\mathrm{P}<0.05$.

Overall mean of $\mathrm{E}_{2}$ concentration pre-treatment increased $(\mathrm{P}<0.05)$ in $\mathrm{G} 3$ and decreased $(\mathrm{P}<0.05)$ in $\mathrm{G} 1$, while did not differ in $\mathrm{G} 2$ as compared to G4. At mating, $\mathrm{E}_{2}$ concentration increased $(\mathrm{P} \leq 0.05)$ in G1 and G2 and decreased $(\mathrm{P}<0.05)$ in $\mathrm{G} 3$ as compared to $\mathrm{G} 4$. This means that OvSynch protocol and CIDR markedly increased $\mathrm{E}_{2}$ concentration, while eCG decreased $\mathrm{E}_{2}$ concentration at mating compared with pre-treatment (Table 6). Of course the trend of change in $E_{2}$ level is in relation with follicular size. In this respect, Derara $\boldsymbol{e t}$ al. (2014) showed that serum $E_{2}$ peaked when a large follicle was detected on day $8.5 \pm 2.8$ post-GnRH treatment, concluding that dromedary camels are highly responsive to early GnRH treatment.

On day 70 post-mating, $\mathrm{E}_{2}$ concentration was lower $(\mathrm{P}<0.05)$ in all treated groups than in control one, showing inconsistent trend of changes at different sampling times (Table 7). The observed increase in overall E2 concentration in OvSynch and CIDR after the end of treatment (at mating) may suggest initiation of new follicular wave after CL regression by PGF2 $\alpha$ in OvSynch group and CIDR removal in CIDR group. In this respect, Ismail et al. (1998) found that PGF2 $\alpha$ injection into a she-camel primed with hCG (having functioning $\mathrm{CL}$ ) during the breeding season induced an increase in plasma estradiol-17 $\beta$ on day 5 post-injection as compared to that pre-treatment. Also, Hussein et al. (2015) reported that the overall $\mathrm{E}_{2}$ profile after CIDR application for 10 days was higher than that after CIDR application for 7 and 14 days, respectively during breeding season.

Table 7. Mean and standard error of progesterone and estrogen concentrations in blood plasma of pregnant and non-pregnant camels within each hormonal protocol.

\begin{tabular}{|c|c|c|c|c|c|c|c|}
\hline \multirow{2}{*}{$\begin{array}{c}\text { Group } \\
\text { (Protocol) }\end{array}$} & \multirow{2}{*}{$\begin{array}{c}\text { Pregnanc } \\
\text { y status }\end{array}$} & \multicolumn{3}{|c|}{ Progesterone level $(\boldsymbol{\mu g} / \mathbf{m l})$} & \multicolumn{2}{c|}{ Estrogen level $(\mathbf{p g} / \mathbf{m l})$} \\
\cline { 3 - 8 } & Pre-treatment & At mating & $\mathbf{7 0 ~ d ~ o f ~ m a t i n g ~}$ & $\begin{array}{c}\text { Pre- } \\
\text { treatment }\end{array}$ & At mating & $\begin{array}{c}\mathbf{7 0} \mathbf{d} \text { of } \\
\text { mating }\end{array}$ \\
\hline G1 & Non-preg. & $0.29 \pm 0.092$ & $2.19 \pm 0.062$ & $3.59 \pm 0.908$ & $0.25 \pm 0.081$ & $6.64 \pm 1.821$ & $0.01 \pm 0.001$ \\
(OvSynch) & Pregnant & $1.06 \pm 0.833$ & $0.19 \pm 0.033$ & $4.63 \pm 1.397$ & $0.14 \pm 0.001$ & $5.45 \pm 1.753$ & $0.03 \pm 0.027$ \\
\hline G2 & Non-preg. & $1.36 \pm 0.000$ & $2.61 \pm 0.000$ & $0.38 \pm 0.000$ & $0.00 \pm 0.000$ & $4.48 \pm 0.000$ & $5.07 \pm 0.000$ \\
(CIDR) & Pregnant & $0.80 \pm 0.457$ & $0.24 \pm 1.641$ & $8.72 \pm 3.449$ & $5.21 \pm 1.095$ & $6.70 \pm 1.991$ & $0.08 \pm 0.064$ \\
\hline G3 & Non-preg. & $0.42 \pm 0.125$ & $2.01 \pm 6.460$ & $1.23 \pm 0.804$ & $7.54 \pm 0.440$ & $1.90 \pm 0.350$ & $2.89 \pm 0.090$ \\
(eCG) & Pregnant & $0.17 \pm 0.022$ & $0.10 \pm 2.108$ & $8.89 \pm 1.574$ & $4.93 \pm 1.804$ & $2.45 \pm 1.500$ & $0.32 \pm 0.292$ \\
\hline \multirow{2}{*}{ G4 (control) } & Non-preg. & $0.85 \pm 0.354$ & $3.17 \pm 1.264$ & $3.43 \pm 1.169$ & $5.97 \pm 1.764$ & $4.12 \pm 0.999$ & $4.45 \pm 0.900$ \\
& Pregnant & $1.19 \pm 1.446$ & $0.67 \pm 5.033$ & $4.37 \pm 4.869$ & $0.01 \pm 0.005$ & $4.85 \pm 6.656$ & $1.82 \pm 0.789$ \\
\hline Overall & Non-preg. & $0.73 \pm 0.411$ & $2.50 \pm 0.258^{\mathrm{a}}$ & $2.16 \pm 0.102^{\mathrm{b}}$ & $3.44 \pm 0.865$ & $4.28 \pm 1.623$ & $3.10 \pm 0.807^{\mathrm{a}}$ \\
mean & Pregnant & $0.81 \pm 0.384$ & $0.30 \pm 0.344^{\mathrm{b}}$ & $6.65 \pm 0.857^{\mathrm{a}}$ & $2.57 \pm 0.705$ & $4.87 \pm 1.402$ & $0.56 \pm 0.060^{\mathrm{b}}$ \\
\hline
\end{tabular}

On the other hand, Chaves et al. (2002) reported that $E_{2}$ concentration in IIama decreased drastically by day one post-insertion of CIDR and remain low until day 6 , when they started to increase again. In addition, these results suggested that the use of exogenous $\mathrm{P}_{4}$ did not synchronize wave emergence in camels as follicular waves continued to emerge during the period of treatment. Similar results were reported by Nikjou et al. (2008).

Overall concentration of $\mathrm{P}_{4}$ pre-treatment was similar in pregnant and non-pregnant camels, reflecting different reproductive statuses of camels within each group before treatment. At mating, overall $\mathrm{P}_{4}$ concentration was lower $(\mathrm{P}<0.05)$ in pregnant $(\leq 0.05 \mathrm{ng} / \mathrm{ml})$ than in non-pregnant $(\geq 1 \mathrm{ng} / \mathrm{ml})$ (Table 6$)$. This trend was noticed 
in all groups. Reducing $\mathrm{P}_{4}$ concentration in pregnant animals below $1.0 \mu \mathrm{g} / \mathrm{ml}$ at mating may indicate complete regression of CL and incidence of estrus in pregnant animals at the time of mating. In this line, Ismail $\boldsymbol{e t}$ al (1998) found that PGF2 $\alpha$ injection into a she-camel primed with hCG (having functioning CL) during the breeding season significantly decreased $\mathrm{P} 4$ level on days 1 and 2 post-injection. Also, they observed increase in plasma P4 to $1.0 \mu \mathrm{g} / \mathrm{ml}$ four days post-hCG injection, reaching its maximum level on day 8 post-injection.

On day 70 post-mating, overall mean of $\mathrm{P} 4$ concentration was higher $(\mathrm{P}<0.05)$ in pregnant than in nonpregnant animals, ranging from 4.366 to $8.894 \mu \mathrm{g} / \mathrm{ml}$ in pregnant camels in all groups (Table 6). Several authors reported that Plasma $\mathrm{P}_{4}$ concentrations recorded in pregnant camels varied from 1.40 to $6.45 \mathrm{ng} / \mathrm{ml}$ (Agarwal et al., 1987\& 1997). In pregnant camels, $\mathrm{P}_{4}$ values are above $1 \mu \mathrm{g} / \mathrm{ml}$ on day 20 post-mating (Dholpuria et al., 2012) or varied from 1.40 to $6.45 \mathrm{ng} / \mathrm{ml}$ (Agarwal et al., 1987\& 1997). However, Quzy et al. (2013) considered camels with P4 values between 1-2 $\mathrm{ng} / \mathrm{ml}$ as doubtful because of the possibility of early embryonic deaths (Dholpuria et al., 2012). This trend was more pronounced in CIDR and eCG groups as a result of increasing pregnancy rate of these groups as compared to other groups.

On the other hand, overall concentration of $\mathrm{E}_{2}$ was higher $(\mathrm{P}<0.05)$ in non-pregnant than in pregnant animals only on day 70 post-mating, reflecting higher ovarian activity in non-pregnant animals during this time in all groups, except for those in OvSynch group (Table 7).

Generally, there was a marked relationship between $\mathrm{P}_{4}$ and $\mathrm{E}_{2}$, in particular at mating, whereas $\mathrm{P}_{4}$ showed the lowest levels versus the highest $\mathrm{E}_{2}$ levels. The correlation between the plasma $\mathrm{P}_{4}$ and $\mathrm{E}_{2}$ levels augments the hypothesis that luteolysis can be induced within 2-4 days and mature follicles can be palpated 3-5 days posts PGF $2 \alpha$ injection (Ismail et al., 1998). Some studies have shown that there is a sharp decline in $\mathrm{P}_{4}$ after luteolysis in camel and mature ovulatory sized follicles are present on the ovaries within 4 to 5 days of treatment (Ismail et al., 1998).

\section{Pregnancy Rate:}

Pregnancy rate of synchronized camels was the highest $(85.71 \%, \mathrm{P}<0.05)$ in $\mathrm{G} 2$, followed by G3 (71.43\%) and G1 (57.14\%), while G1 showed the lowest pregnancy rate $(42.86 \%, \mathrm{P}<0.05)$. These results indicated significant improvement of camel fertility in all treated groups as compared to control one, being the best in camels treated with CIDR plus eCG, followed by those treated with eCG and PGF2 $\alpha$ (Table 8). The physiological explanation for this increase may be attributed to that the eCG molecule has FSH-like activity which might have enhanced the follicular development accelerating the existence of the dominant follicle and subsequently causing ovulation via its LH-like action (Al-Sobayil, 2008).

Table 8. Pregnancy rate of camels as affected by hormonal protocol.

\begin{tabular}{|l|c|c|c|}
\hline \multicolumn{1}{|c|}{ Protocol } & $\begin{array}{c}\text { Treated/inseminated animals } \\
(\mathbf{n})\end{array}$ & Pregnant animals (n) & Pregnancy rate $(\boldsymbol{\%})$ \\
\hline G1 (OvSynch) & 7 & 4 & $57.14 \pm 12.3^{\mathrm{c}}$ \\
\hline G2 (CIDR) & 7 & 6 & $85.71 \pm 15.8^{\mathrm{a}}$ \\
\hline G3 (eCG) & 7 & 5 & $71.43 \pm 10.3^{\mathrm{b}}$ \\
\hline G4 (Control) & 7 & 3 & $42.86 \pm 12.3^{\mathrm{d}}$ \\
\hline
\end{tabular}

Overall means denoted within the same column with different superscripts are significantly different at $\mathrm{P}<0.05$.

In accordance with the present results, Al-Sobayil (2008) found that the highest calving rate (80\%) was achieved when PRID was followed by eCG. This result agreed with that obtained earlier by Simpkin (1987) when a 15-day progestogen treatment followed by the administration of 1500-2500 IU eCG. The later authors reported that an eCG dose guarantees the presence of mature follicle(s) and subsequent ovulation. Also, Tibary and Anouassi (2000) reported that the synchronization of follicular development and ovulation is improved by the administration of 1500-2000 IU eCG one day before the PRID removal, or the last day of progestogen treatment. In comparable with the present rates of pregnancy, Quzy et al. (2013) found that lower pregnancy rates than that reported in our study, being 50.0, 65.11 and 61.53\% in control, eCG (2000 IU) and OvSynch treated camels, respectively.

It is of interest to note that the effect of hormonal treatment on camel fertility was associated with significant effect on number and diameter of CL of pregnant camels. Total number of CL per animal decreased $(\mathrm{P}<0.05)$ in all treated groups, while $\mathrm{CL}$ diameter decreased $(\mathrm{P}<0.05)$ decreased in OvSynch group only as compared to control one (Table 9). Shalash (1965) and Elias et al. (1984) reported that CL could be palpated 810 days post mating. 
Improving Fertility of Maghrabian She-Camels Treated with Different Hormonal Treatments during...

Table 9. Average of number and diameter of corpora lutea on the left and right ovary of pregnant camel on day 70 post-mating as affected by hormonal protocol.

\begin{tabular}{|l|c|c|c|c|c|c|}
\hline \multirow{2}{*}{$\begin{array}{c}\text { Group } \\
\text { (Protocol) }\end{array}$} & \multicolumn{3}{|c|}{ Number of CL } & \multicolumn{3}{c|}{ Diameter (mm) of CL } \\
\cline { 2 - 7 } & $\begin{array}{c}\text { Right } \\
\text { ovary }\end{array}$ & Left ovary & Total & $\begin{array}{c}\text { Right } \\
\text { ovary }\end{array}$ & Left1 ovary & Overall mean \\
\hline G1 (OvSynch) & $1.25 \pm 0.22^{\mathrm{b}}$ & $1.00 \pm 0.00^{\mathrm{b}}$ & $2.30 \pm 0.20^{\mathrm{b}}$ & $16.33 \pm 0.481^{\mathrm{b}}$ & $19.60 \pm 1.191^{\mathrm{b}}$ & $18.01 \pm 1.191^{\mathrm{b}}$ \\
\hline G2 (CIDR) & $1.50 \pm 0.22^{\mathrm{ab}}$ & $1.00 \pm 0.00^{\mathrm{b}}$ & $2.50 \pm 0.20^{\mathrm{b}}$ & $18.33 \pm 1.734^{\mathrm{ab}}$ & $22.75 \pm 0.594^{\mathrm{a}}$ & $20.51 \pm 0.826^{\mathrm{a}}$ \\
\hline G3 (eCG) & $1.20 \pm 0.41^{\mathrm{b}}$ & $1.40 \pm 0.20^{\mathrm{ab}}$ & $2.60 \pm 0.40^{\mathrm{b}}$ & $21.00 \pm 0.289^{\mathrm{a}}$ & $19.63 \pm 0.515^{\mathrm{b}}$ & $20.30 \pm 0.515^{\mathrm{a}}$ \\
\hline G4 (Control) & $2.00 \pm 0.00^{\mathrm{a}}$ & $2.00 \pm 0.00^{\mathrm{a}}$ & $4.00 \pm 0.00^{\mathrm{a}}$ & $21.00 \pm 0.000^{\mathrm{a}}$ & $19.17 \pm 0.612^{\mathrm{b}}$ & $20.09 \pm 0.518^{\mathrm{a}}$ \\
\hline
\end{tabular}

Means denoted within the same column with different superscripts are significantly different at $\mathrm{P}<0.05$.

\section{Conclusion}

Administration of eCG (1000 IU), as it contains mainly the FSH-like activity and partially the LH-like activity, $48 \mathrm{~h}$ prior to CIDR insertion for 10 days or 10 days prior to PGF2 $\alpha$ injection, caused a better synchrony of estrus and ovulation, and improved pregnancy rate of camels. For achieving an appropriate estrous synchronization of dromedary camels during breeding season, the estrus and ovulation could be hormonally induced by CIDR insertion for 10 days and eCG injection on day 8 ( $48 \mathrm{~h}$ before CIDR withdrawal) with the highest pregnancy rate. The use of OvSynch did not exceed the pregnancy rate. Further studies are needed to monitor the failure of OvSynch protocol to improve fertility of she-camels during breeding season.

\section{References}

[1] Agarwal, R., West, C., Conway, G.S., Page, M.L. and Jacobs, H.S. (1997). Pregnancy after treatment with three recombinant gonadotrophins. Lancet, 349, 29-30.

[2] Agarwal, S.P., Khanna, N.D., Agarwal, V.K. and Dwaraknath, P.D. (1987). Circulating level of oestrogen and progesterone in female camels (Camelus dromedarius) during pregnancy. Theriogenology, 28, 849-859.

[3] Agarwal, S.P.; Rai, A.K. and Khanna, N.D. (1993). Effect of low dose of FSH administration on ovarian activity during nonbreeding season in the camels. Indian J. Anim. Sci., Vol. 63:387-390.

[4] Al-Sobayil, K.A. (2003). Hormonal treatments for inducing fertile estrus in young dromedary females at the end of their seasonal anestrus in Qassim region, Saudi Arabia. J. Camel Practice and Research, (December 2003): 179-181.

[5] Al-Sobayil, K.A. (2008). The use of estrus synchronization and timed artificial insemination in dromedary she-camels in Saudi Arabia. Journal of Agricultural and Veterinary Sciences, Qassim University, Vol. 1, No. 1: 3-9.

[6] Anouassi, A. and Ali, A. (1991). Embryo transfer in camel (Camelus dromedarius). Camel Newsletter, 8:20

[7] Anouassi, A., Tibary, A., Adnani, M. and Sghiri, A. (1994). Preovulatory phase characterization in Camelus dromedarius and induction of ovulation. Proceedings of the Conference Organized by FIS. Niamey, Niger. pp 159-167.

[8] Bono, G., Dahir, A.M., Comin, A. and Jumale, A.M. (1991a). Seasonal effects on the endocrine reproductive activity of the dromedary camel. Camel Newsletter, 8:22.

[9] Bono, G., Jumale, A.M. and Dahir, A.M. (1991b). Seasonal variations of LH response to GnRH treatment in camels (Camelus dromedarius). Camel Newsletter, 8:19.

[10] Chaves, M.G., Aba, M.A., Agüero, A., Egey, J., Berestin, V. and Rutter, B. (2002). Ovarian follicular wave pattern and the effect of exogenous progesterone on follicular activity in non-mated llamas. Anim. Reprod. Sci., 69, 37-46.

[11] Chen, B.X.; Yuen, Z.X. and Pan, G.W. (1985). Semen induced ovulation in the Bactrian camel (Camelus bactrinus). J. Reprod. Fertil., Vol. 74, 335-339.

[12] Combarnous, Y. and Anouassi, A. (1994). Radioimmunoassay and enzyme-linked immuno-sorbent assay technique as aid to studying pituitary hormones and improving reproductive management of the one humped camel. J. Arid. Enviro., Vol. 26, 15-20.

[13] Dahir, M.A.; Jumale, A.M.; Halane, M.I. and Prandi, A. (1990). Effect of progestogen-PMSG treatment on estrus activity of shecamel dromedaries at the end of the dry season. Proceedings of the Workshop "Is It Possible to Improve the Reproductive Performance of the Camel?", Paris, France, pp 189-195.

[14] Derara, R.; Ali, A. and Al-Sobayil, F.A. (2014). The postpartum period in dromedary camels: Uterine involution, ovarian activity, hormonal changes, and response to GnRH treatment. Animal Reproduction Science, 151:186-193.

[15] Dholpuria, S., Vyas S., Purohit G.N. and Pathak K.M.L. (2012). Sonographic monitoring of early follicle growth induced by melatonin implants in camel and the subsequent fertility. J. Ultrasound., 15: 135-141.

[16] Duncan, D.B. (1955). Multiple Range's and Multiple F-test. Biometrics, 11: 1-42.

[17] Elias, E.; Bedrak, E. and Cohen, D. (1985). Induction of estrus in camel (Camelus dromedaries) during seasonal anestrus. J. Reprod. Fert., Vol. 74: 519-525.

[18] Elias, E.; Bedrak, E. and Yagil, R. (1984). Peripheral blood levels of progesterone in female camels during various reproductive stages. General and Comparative Endocrinology, Vol. 53: 235-240.

[19] Hafez, E.S. and Hafez, B. (2001). A Review: Reproductive Parameters of Male Dromedary and Bactrian Camels. Arch. Androl., Vol. 4: 85-98.

[20] Homeida, A.M.; Khalil, M.G.R. and Taha, A.A.M. (1988). Plasma Concentration of Progesterone, Estrogen, Testosterone and LHlike Activity During the Estrus Cycle of the Camel (Camelus dromedarius). J. Reprod. Fert., Vol. 83: 593-598.

[21] Hussein, F.M., Metwelly, K.K., Mahmoud, Mona, A. and Ragab, Mohamed H. (2015). Effect of CIDR application duration (7-1014 Days) on circulating estrogen and progesterone during breeding and non-breeding season in she-camels. Alexandria Journal of Veterinary Sciences, 44: 125-129.

[22] Ismail, A.A.; Siam, A.A.; Amal El-Nahla and S.M.M. Abuzead (1998). Synchronization of estrus in the she-camel. Proceedings of the Third Annual Meeting for Animal Production Under Arid Conditions, Vol. 1: 96-107. United Arab Emirates University.

[23] Kaufmann, B.A. (2005). Reproductive performance of camels (Camelus dromedarius) under pastoral management and its influence on herd development. Livestock Production Science, 92: 17-29. 
[24] Manjunatha, B.M., David, C.G., Pratap, N., Al-Bulushi, S. and Hago, B.E. (2012). Effect of progesterone from induced corpus luteum on the characteristics of a dominant follicle in dromedary camels (Camelus dromedarius). Anim. Reprod. Sci., 132 (3-4): 231-236.

[25] McKinnon, A.O.; Tinson, A.H. and Nation, G. (1994). Embryo transfer in dromedary camels. Theriogenology, Stoneham, Mass.: Butterworth-Heinemann, 41 (1): 145-150.

[26] Minoia, P.; Moslah, M.; Lacalandra, G.M.; Khorchani, T. and Zarilla, A. (1992). Induction of estrus and management of reproduction in the female dromedary camel. Proceedings of the $1^{\text {st }}$ International Camel Conference, 119-123. Edited by W.R. Allen, A.J. Higgins, I.G. Maybew, D.H. Snow and J.F. Wade. R \& W Publications (Newmarket) Ltd.

[27] Monaco, D.; Lacalandra, G.M.; El-Hassanein, E.E.; Rateb, S.; Salama, O. and El-Bahrawy, K.A. (2012). Effect of a controlled intravaginal drug releaser (CIDR) and GnRH administration on ovarian follicular dynamics of female dromedary camel during seasonal anestrus period. Proc $3^{\text {rd }}$ Conf Int. Soc. Camelid Res. Dev. Jan., 29-Feb, Muscat, Sultanate of Oman, p $123-24$.

[28] Musa, B.H.; Sieme, H.; Hago, B.; Cooper, M. J.; Allen, W. R. and Jochle, W. (1993). Manipulation of Reproductive Function in Male and Female Camels. Anim. Repro. Sci., Vol. 33: 289-306.

[29] Nikjou, D., Niasari-Naslaji, A., Skidmore, J.A., Mogheiseh, A., Razavi, K., Germai, A. and Ghanbari, A. (2008). Synchronization of follicular wave emergence prior to superovulation in Bactrian camel (Camelus bactrianus). Theriogenology, 69:491-500.

[30] Quzy, I., Anwar, S. and Purohit, G.N. (2013). Hormonal management of ovarian activity in breeding camels two months ahead of the natural breeding season. Camel- International Journal of Veterinary Science, 1(1):37-49.

[31] SAS (2004). SAS/STAT User's Guide: Volumes 1-7. SAS Institute Inc., Cary, North Carolina.

[32] Shalash, M.R. (1987). Review Article: Reproduction in camels. Egypt J. Vet. Sci., Vol. 24: 1-25.

[33] Shalash, M.R. (1965). Some reproductive aspect in the female camel." World Rev. Anim. Prod., Vol. 4: 103-108.

[34] Simpkin, S.P. (1987). A summary of the increased productivity in camels as a result of application of a veterinary program. Proc. Workshop Camel Management and Ecology, Landskrona, Sweden.

[35] Skidmore, J.A.; Billah, M. and Allen, W.R. (1996). The ovarian follicular wave pattern and induction of ovulation in the mated and non-mated one humped camel (Camelus dromedarius). J. Reprod. Fertil. 106:185-92.

[36] Skidmore, J.A.; Adams, G.P. and Billah, M. (2009). Synchronization of ovarian follicular waves in the dromedary camel (Camelus dromedarius). Anim. Reprod. Sci., 114:249-255.

[37] Tibary, A. and Anouassi, A. (1996). Ultrasonographic changes of the reproductive tract in the female camel (Camelus dromedarius) during the follicular cycle and pregnancy. J. of Camel Practice and Research, Vol. 3: 71-90.

[38] Tibary, A. and Anouassi, A. (1997). Theriogenology in Camelidae: Anatomy, Physiology, Pathology, and Artificial Breeding. Mina, UAE: Abo Dhabi Printing and Publishing Company, pp. 51-61, 171-173.

[39] Tibary, A. and Anouassi, A. (2000). Ultrasonography of the genital tract in camels (Camelus dromedarius and Camelus bactrianus). In: Gahlot, T.K. (Ed.), Selected Topics in Camelid Medicine. The Camelid Publishers, Bikaner, India, pp. 431-465. 